\title{
Electrochemical Behaviour of Some Amino Acids as Corrosion Inhibitors for Mild Steel in Sweet Brine
}

\author{
León González JPa, Onofre Bustamante $\mathrm{E}^{\mathrm{a}}$, Rodríguez Gómez $\mathrm{F}^{\mathrm{b}}$, Espinoza Vázquez A \\ ${ }^{a}$ Instituto Politécnico Nacional, Centro de Investigación en Ciencia Aplicada y Tecnología Avanzada, Unidad Altamira, México \\ ${ }^{b}$ Universidad Nacional Autónoma de México, Facultad de Química, Departamento de Ingeniería Metalúrgica, Ciudad de México \\ 'Universidad Nacional Autónoma de México, Instituto de Investigaciones en Materiales, Ciudad de México
}

Received: February 15, 2021; Accepted: February 22, 2021; Published: February 28, 2021

*Corresponding author: Onofre Bustamante E, Instituto Politécnico Nacional, Centro de Investigación en Ciencia Aplicada y Tecnología Avanzada, Unidad Altamira, México, Tel. No: 528332600125 EXT. 87516; E-mail: eonofre@ipn.mx

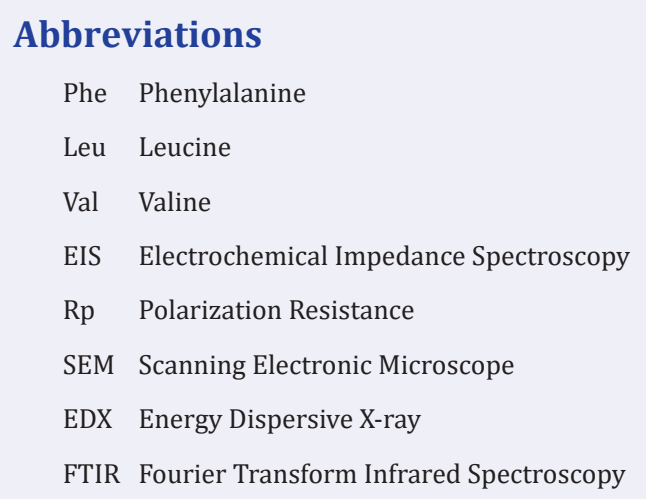

\begin{abstract}
The effect of concentration and immersion time of phenylalanine (Phe), leucine (Leu) and valine (Val) for AISI 1018 in sweet brine was studied trough Electrochemical Impedance Spectroscopy (EIS), polarization resistance (Rp), Scanning Electronic Microscope (SEM) and Fourier Transform Infrared Spectroscopy (FTIR) as an ecological and biodegradable alternative as corrosion inhibitors. Electrochemical results showed that amino acids are good corrosion inhibitors according to their charge transfer resistance improvement. The effect of immersion time on corrosion behavior was studied trough $24 \mathrm{~h}$ with amino acids concentration variation of 0,10,100 and $250 \mathrm{ppm}$. The preliminary results demonstrated that the three amino acids adsorb over metal surface following the Langmuir adsorption isotherm model, and tend to agglomerate in bulk within time.
\end{abstract}

Keywords: Corrosion Inhibitors; Biodegradable; Amino acids; Sweet brine

\begin{abstract}
In spite of all developments in new technologies; the search of new oil sources is utmost importance due to the energy growing demand [1]. It comes with new challenges to inhibit corrosion in extraction and transportation systems [2] without neglecting the ecological issue. Recently some researchers such as A.A [3] mentioned that the use of synthetic organic inhibitors in oil and gas industry leads to stricter environmental regulations to their usage; making thus necessitated the research of new natural; inexpensive and environmentally friendly corrosion inhibitors. In this way the presence of functional groups; heteroatoms and multiple bonds make organic compounds a good option as corrosion inhibitors[4], due to this; amino acids have been used as corrosion inhibitors for several metals and alloys in different electrolytes for multiple applications.However; their efficiency depends on many factors; such as inhibitor and oxygen concentration; metal and compound chemical nature; surface
\end{abstract}

preparation of metal; immersion time; hydrodynamic conditions; temperature; $\mathrm{pH}$ and additives [5].

In general; it has been determinate that amino acids have higher anticorrosive efficiency in neutral and acidic solutions; due to the protonation of the amino group; adsorbing and blocking the active sites for the corrosion process [6]. Amino acids adsorb over metal surface following different adsorption models. In 2017; H.T.M. Abdel-Fatal et al determinate that tryptophan was a good corrosion inhibitor for mild steel in $\mathrm{HSO}_{3} \mathrm{NH}_{2}$ and $\mathrm{HCl}$ acid solutions obeying Temkin adsorption isotherm model. On the other hand [7] determinates that the L-histidine as corrosion inhibitor obeys Langmuir adsorption isotherm model.

Additionally it was determinate that the concentration is a decisive factor for a corrosion inhibitor; many authors have used amino acids in a wide range of concentrations in order to achieve high corrosion inhibition efficiencies; from tens of ppm (0-99 
ppm) [8-10] followed by hundreds of ppm (100-999 ppm)[11-13] to thousands of ppm(+1000 ppm) [14,15]. Due to this; the amino acids: phenylalanine (Phe); leucine (Leu) and valine (Val) (Figure. 1) are proposed as an eco-friendly alternative as corrosion inhibitors for AISI 1018 in a sweet brine for an application in oil industry.<smiles>NC(Cc1ccccc1)C(=O)O</smiles>

Phenylalanine<smiles>CC(C)C[C@H](N)C(=O)O</smiles>

Leucine<smiles>CC(C)[C@H](N)C(=O)O</smiles>

Valine
Figure 1: Schematic of inhibitor's molecular structures

\section{Experimental Procedure}

\section{Surface Preparation and electrochemical cell}

Before the electrochemical tests; the working electrode samples were prepared by abrasion with emery paper to a 2000-grade; a subsequent cleaning with deionized water and acetone and dried at room temperature $\left(25^{\circ} \mathrm{C}\right)[16]$. The electrolyte was a sweet brine composed of a brine solution NACE $\left(\mathrm{NaCl} 106.58 \mathrm{~g} / \mathrm{L} ; \mathrm{CaCl}_{2} \bullet 2 \mathrm{H}_{2} \mathrm{O} 4.48 \mathrm{~g} / \mathrm{L}\right.$ and $\mathrm{MgCl}_{2} \bullet 6 \mathrm{H}_{2} \mathrm{O} 2.96 \mathrm{~g} / \mathrm{L}$ ) and $\mathrm{CO}_{2}(\mathrm{~g})$ until saturation ( $\left.\mathrm{pH}=3.9\right)$. The amino acids (Phe;Leu; Val) were reagent grade $(\geq 98 \%)$ from Sigma Aldrich. Inhibitor concentrations were $0 ; 10 ; 100$ and $250 \mathrm{ppm}$.

\section{Electrochemical characterization}

The electrochemical characterization was carried out using a GillAC potentiostat with a typical tree-electrode electrochemical cell composed of an AISI 1018 alloy as working electrode; graphite rod as counter-electrode and a saturated $\mathrm{Ag} / \mathrm{AgCl}$ reference electrode. Electrochemical Impedance Spectroscopy (EIS) was carried out employing a sinusoidal perturbation signal of \pm 10 $\mathrm{mV}$ vsEcorr; within a frequency range of $10^{-2} \mathrm{~Hz}$ to $10^{4} \mathrm{~Hz}$ after rest potential monitoring during $1800 \mathrm{~s}$. After EIS evaluation; a rest potential monitoring was performed during $300 \mathrm{~s}$; then a perturbation of $\pm 20 \mathrm{mV} v s_{E c o r r}$ was applied in order to evaluate linear polarization resistance. The experimental data was fitted by ZView 2 software

\section{Morphological Characterization}

Samples were immersed in the sweet brine with the optima concentration of each amino acid; during $24 \mathrm{~h}$ at room temperature. After immersion; specimens were washed with distilled water and dried in open-air inside a desiccator. The surface was analyzed using a Carl-Zeiss microscope SUPRA 55 $\mathrm{VP}$ at $5 \mathrm{kV}$ accelerating voltage; wirth a $500 \mathrm{X}$ secondary electro detector.

\section{Spectroscopic characterization}

For Fourier Transform Infrared spectroscopic characterization; electrolyte samples were taken at the beginning of the tests and after seven days and were analyzed on a Perkim Elmer Spectrum One in the range of 650 to $4000 \mathrm{~cm}^{-1}$.

\section{Results and Discussion}

\section{Electrochemical characterization}

\section{Electrochemical Impedance Spectroscopy (EIS)}

Nyquist plots of AISI 1018 in the sweet brine in absence and presence of Phe during $24 \mathrm{~h}$ of immersion can be appreciated in figure2; which seem to appear as depressed semicircles caused by the heterogeneity of the metal surface [17]. At time $t=0 \mathrm{~h}$ (Figure. 2a)Phe at $10 \mathrm{ppm}$ presents the higher impedance value (2442 $\Omega \mathrm{cm} 2)$; this is attributed to the decrease of molecular mobility with the increase of Phe concentration [18].This tendency persists during the first $12 \mathrm{~h}$ (Figure $2 \mathrm{~b} ; 2 \mathrm{c}$ ); and after $24 \mathrm{~h}$ of immersion (Figure. $2 \mathrm{~d}$ ) the the Phe at $10 \mathrm{ppm}$ remains stable and the other systems achieves similar values; due to oxide formation and amino acid adsorption.

Bode angle plots of AISI 1018 in absence and presence of different concentrations of Phe are shown in figure 3; after $6 \mathrm{~h}$ of immersion (Figure. 3a; 3b) can be appreciated only one time constant due to the inhibitor film resistance (Rf); and after 12 and $24 \mathrm{~h}$ (Figure. 3c; 3d) there is an arc widening; associated to the presence of a second time constant of the charge transfer resistance (Rct)[19]; furthermore; the wide frequency range covered by the phase angle signal provides information on a strong adsorption process over the substrate [20] and the increasing of the phase angle values with the addition of the amino acid means of a formation of a higher protection layer [21].

In order to simulate the response acquired by EIS of all systems; the equivalent circuits in Figure. 4 were used by fitting to the lowest error. Figure 4a shows the circuit used for the first $6 \mathrm{~h}$ of immersion and for the 12 and $24 \mathrm{~h}$ of immersion the two elements circuit in Figure. 4b was used.

Due to surface heterogeneity [22], a Constant Phase Element (CPE) was used instead of capacitances (C) for a more accurate fitting to EIS results. The CPE is defined in impedance 
representation by the following equation:

$$
Z_{C P E}=Y_{0}^{-1}(j \omega)^{-n}
$$

where $Y_{0}$ is a proportional factor; $n$ is the phase shift. The CPE may represent a resistance ( $\mathrm{n}=0$ ); a capacitor $(\mathrm{n}=1)$; or an inductance $(n=-1)$. The double layer capacitance $\left(C_{d l}\right)$ is represented by;

$$
C_{d l}=Y_{0}\left(\omega_{m}^{\prime \prime}\right)^{n-1}
$$
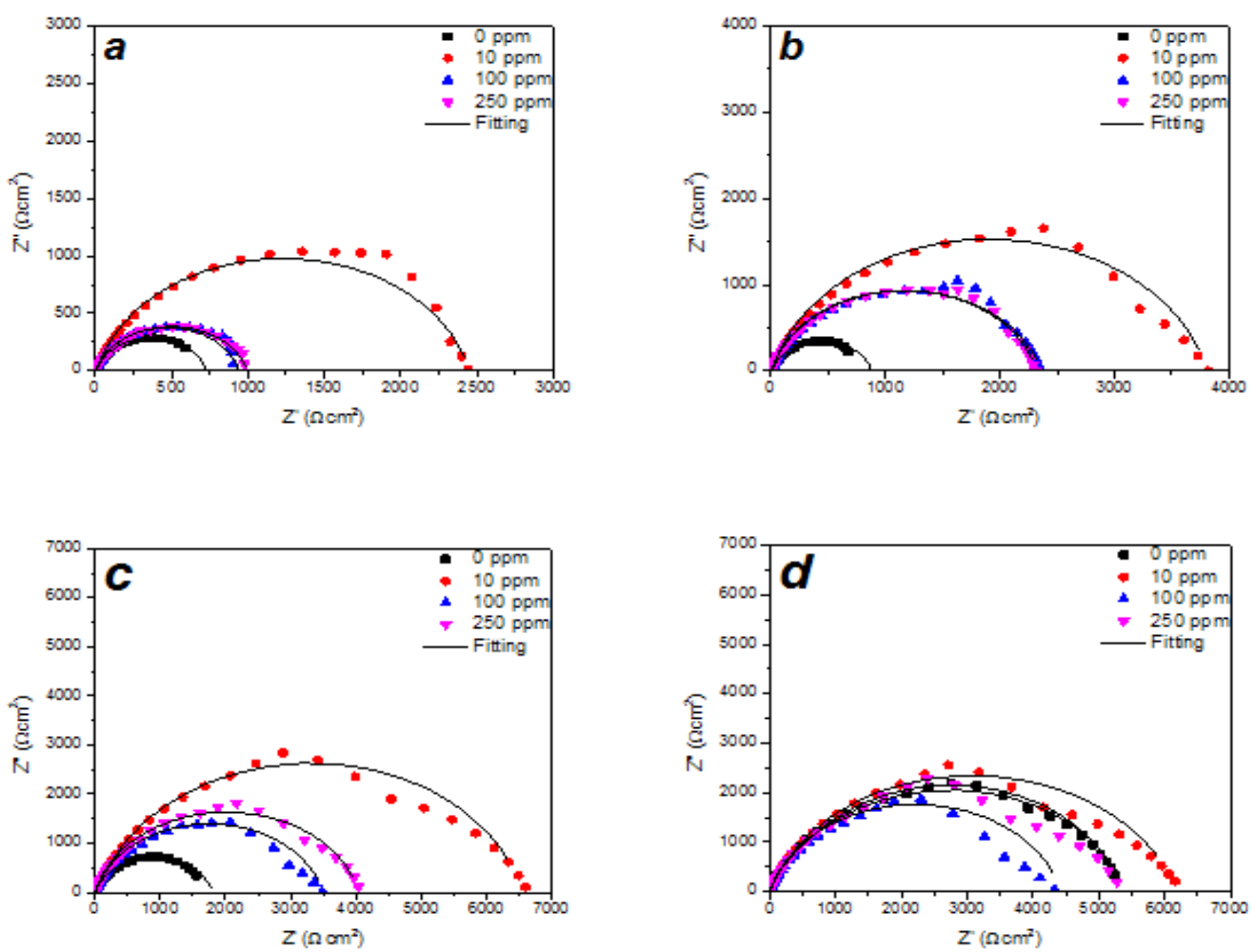

Figure 2: Nyquist plots for AISI 1018 in a brine solution NACE + CO2 in absence and presence of Phe after a) 0 h, b) 6 h, c) 12 h and d) 24 h of immersion
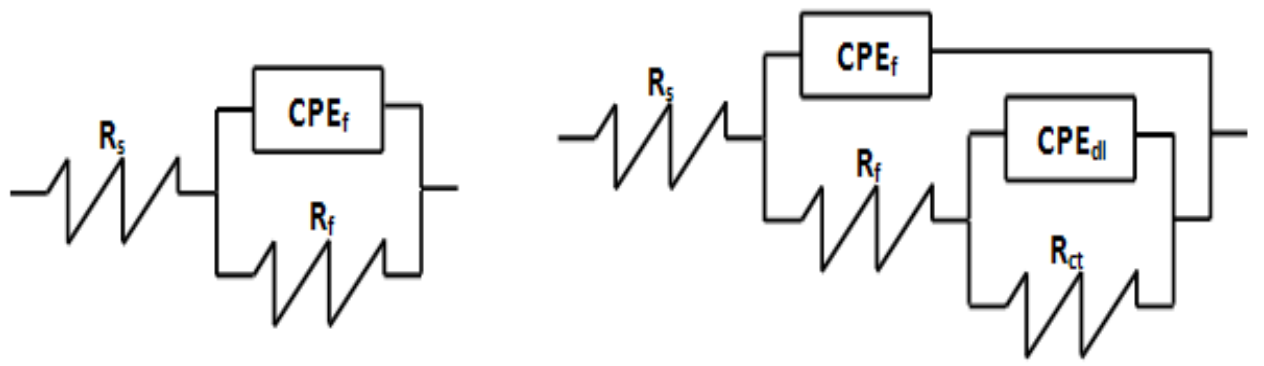

Figure 4: Equivalent circuits used for EIS results simulation for a) 0 and $6 \mathrm{~h}$ of immersion and b) for 12 and $24 \mathrm{~h}$ of immersion 

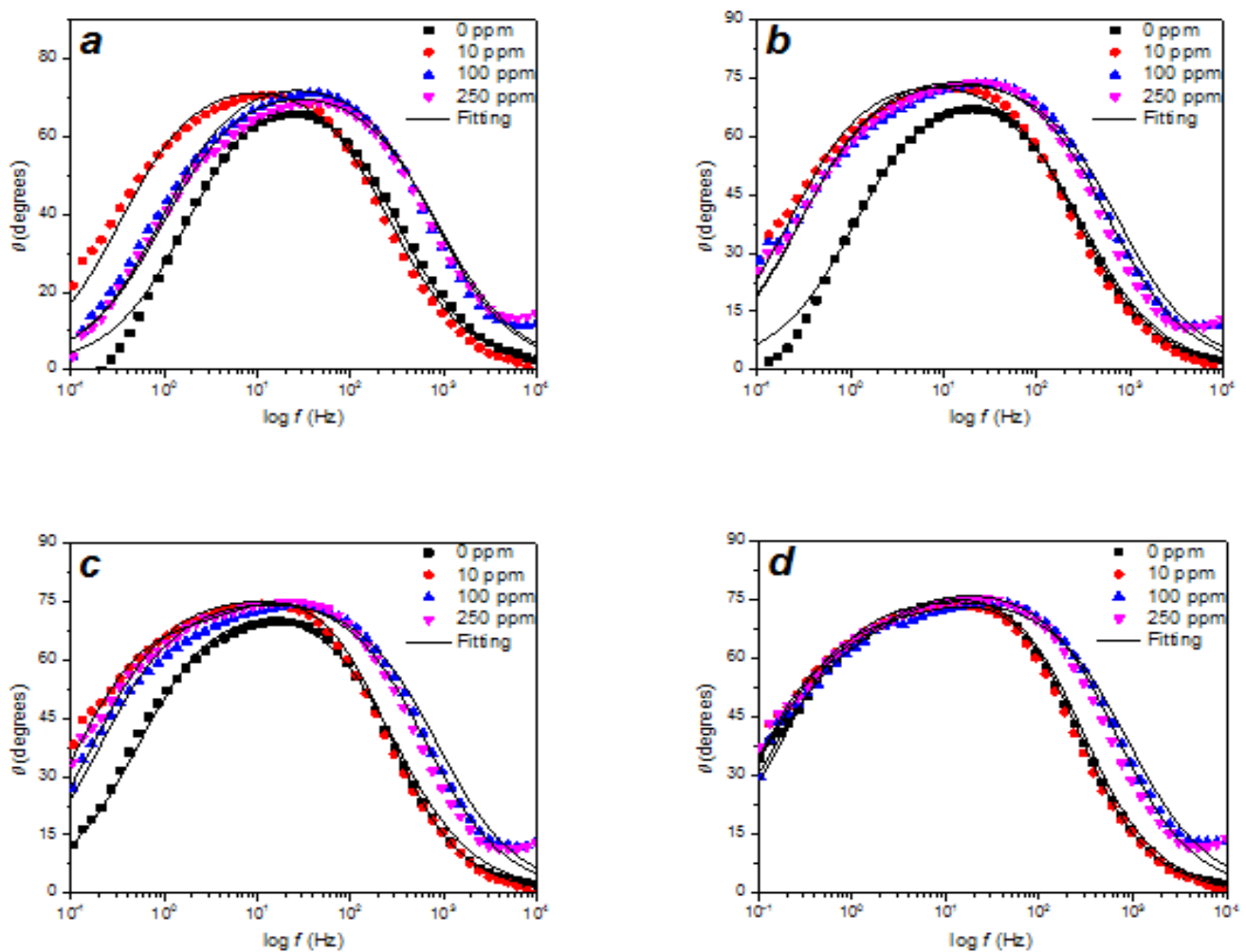

Figure 3: Bode plots of AISI 1018 in a brine solution NACE $+\mathrm{CO}_{2}$ in abbsence and presence of Phe after a) $\left.\left.0 \mathrm{~h}, \mathrm{~b}\right) 6 \mathrm{~h}, \mathrm{c}\right) 12 \mathrm{~h}$ and d) $24 \mathrm{~h}$ of immersion

Where $\omega_{-} \mathrm{n}^{\wedge}$ " is the angular frequency in which the imaginary component of the impedance has a maximum value. Further $n$ can be used as a measurement of the heterogeneity or roughness of the surface[23].

The obtained data from the fitting of the impedance results from AISI 1018 in the sweet brine and the addition of Phe are given in Table 1. As can be seen; with the presence of Phe; the Rct increases; meaning in the formation of a protective film over the surface; in addition the double layer capacitance ( $\mathrm{Cdl}$ ) values decrease due to the adsorption of the amino acid on the surface which changes in the dielectric properties of water molecules on the double layer by changing the orientation of the dipole molecules[24]. Besides this; the effect of the addition of Phe can be seen also by the decrease of the corrosion current density (icorr) meaning in a lowering of the corrosion rate (CR;in mm/y).

In Figure 5 are appreciated the Nyquist plots of Leu; at beginning of the test (Figure 5a) the amino acid provides low corrosion protection in comparison with blank; nearly of $10 \%$ of impedance improvement; which enhances within time. After 6 and $12 \mathrm{~h}$ of immersion (Figure $5 \mathrm{~b} ; 5 \mathrm{c}$ ) the impedance value of Leu at $250 \mathrm{ppm}$ increases 70\% in comparison with AISI 1018 in absence of the Leu. However; after $24 \mathrm{~h}$ (figure $5 \mathrm{~d}$ ) the oxide products formed over the surface provide similar protection than that provided by the amino acid.

Figure 6 shows Bode angle plots of the system with variation of concentration and time immersion; during the first $6 \mathrm{~h}$ of immersion (Figure 6a; 6b) can be appreciated only one time constant associated to the film resistance. After 12 and $24 \mathrm{~h}$ of immersion time (figure $6 \mathrm{c} ; 6 \mathrm{~d}$ ); the widening in frequency of the phase angle signal implies the apparition of a second time constant associated to the charge transfer resistance. Compared with Phe; the phase angle value in presence of Leu increases to a lesser extent; which is associated with a lower adsorption of the amino acid since it slightly increases the capacitive behavior; which is reflected in the lower impedance values reported in Nyquist diagrams.

The data obtained by fitting the EIS experimental results are shown in Table 2; as can be appreciated; the capacitance of the double layer slightly decreases with the addition of Leu to the system what agrees with the small amount of increment in the diameter of the Nyquist plots compared with the results of the addition of Phe.The Nyquist plots for the addition of Val are shown in Figure 7; where can be appreciated that from time $\mathrm{t}=0 \mathrm{~h}$ (Figure 7a) the corrosion inhibitor effect is evident and proportional to Val concentration; achieving the higher impedance value (1826 $\Omega \mathrm{cm}^{2}$ ) at concentration of $250 \mathrm{ppm}$. This behavior persists during all $24 \mathrm{~h}$ of test (Figure $7 \mathrm{~b} ; 7 \mathrm{c} ; 7 \mathrm{~d}$ ) providing corrosion protection in the sweet brine. The increase of the phase angle value in the Bode plots (Figure 8) with the addition of the Val implies the formation of the protection layerwhich matches with the impedance enhancing seen in the Nyquist diagrams. During the first $6 \mathrm{~h}$ of immersion in the sweet brine (Figure 8a; 8b) can only 

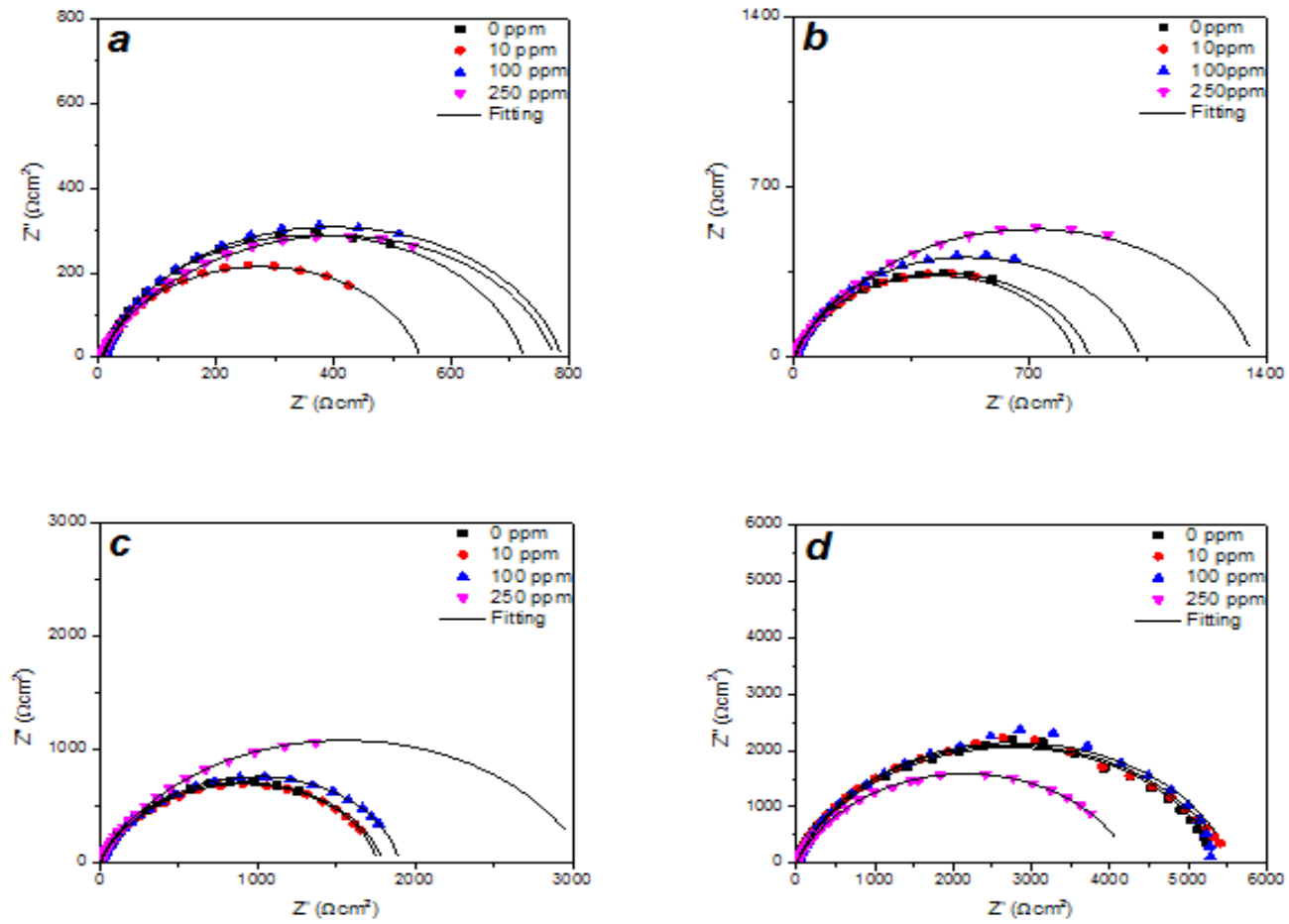

Figure 5: Nyquist plots for AISI 1018 in a brine solution NACE $+\mathrm{CO}_{2}$ in absence and presence of Leu after a) $\left.\left.0 \mathrm{~h}, \mathrm{~b}\right) 6 \mathrm{~h}, \mathrm{c}\right) 12 \mathrm{~h}$ and d) $24 \mathrm{~h}$ of immersion

\begin{tabular}{|c|c|c|c|c|c|c|c|c|}
\hline $\begin{array}{c}\text { C } \\
\text { (ppm) }\end{array}$ & $\begin{array}{c}\text { t } \\
\text { (h) }\end{array}$ & $\begin{array}{c}\mathbf{R}_{\mathrm{f}} \\
\left(\Omega \mathrm{cm}^{2}\right)\end{array}$ & $\begin{array}{c}C_{f}\left[\times 10^{-4}\right] \\
\text { (F) }\end{array}$ & $\begin{array}{c}R_{\mathrm{ct}} \\
\left(\Omega \mathrm{cm}^{2}\right)\end{array}$ & $\begin{array}{c}\mathrm{C}_{\mathrm{dl}}\left[\mathrm{x10}^{-4}\right] \\
\text { (F) }\end{array}$ & $\begin{array}{c}\mathbf{R}_{\mathrm{p}} \\
\left(\Omega \mathrm{cm}^{2}\right)\end{array}$ & $\begin{array}{c}i_{\text {corr }}\left[\times 10^{-}\right. \\
5] \\
\left(\mathrm{A} / \mathrm{cm}^{2}\right)\end{array}$ & $\begin{array}{c}\text { CR } \\
(\mathrm{mm} / \mathrm{y})\end{array}$ \\
\hline \multirow{4}{*}{0} & 0 & - & - & 715 & 1.23 & 715 & 3.64 & 0.421 \\
\hline & 6 & - & - & 870 & 1.61 & 870 & 2.99 & 0.346 \\
\hline & 12 & - & - & 1791 & 1.67 & 1791 & 1.45 & 0.168 \\
\hline & 24 & 1663 & 1.17 & 3735 & 1.23 & 5398 & 0.482 & 0.055 \\
\hline \multirow{4}{*}{10} & 0 & 2442 & 1.90 & - & - & 2442 & 1.06 & 0.123 \\
\hline & 6 & 3798 & 1.86 & - & - & 3798 & 0.685 & 0.079 \\
\hline & 12 & 1211 & 1.07 & 5325 & 0.853 & 6536 & 0.398 & 0.046 \\
\hline & 24 & 652.1 & 0.995 & 5558 & 0.928 & 6210.1 & 0.419 & 0.048 \\
\hline \multirow{4}{*}{100} & 0 & 936 & 1.83 & - & - & 936 & 2.78 & 0.321 \\
\hline & 6 & 2349 & 2.34 & - & - & 2349 & 1.11 & 0.128 \\
\hline & 12 & 582.8 & 1.24 & 3540 & 0.130 & 4098.8 & 0.634 & 0.073 \\
\hline & 24 & 652.5 & 1.16 & 5311 & 0.171 & 5963.5 & 0.436 & 0.050 \\
\hline \multirow{4}{*}{250} & 0 & 991.2 & 1.65 & - & - & 991.2 & 2.62 & 0.303 \\
\hline & 6 & 2311 & 2.40 & - & - & 2311 & 1.13 & 0.130 \\
\hline & 12 & 1073 & 1.47 & 3115 & 1.02 & 4188 & 0.621 & 0.071 \\
\hline & 24 & 1605 & 1.47 & 3790 & 1.28 & 5395 & 0.482 & 0.055 \\
\hline
\end{tabular}



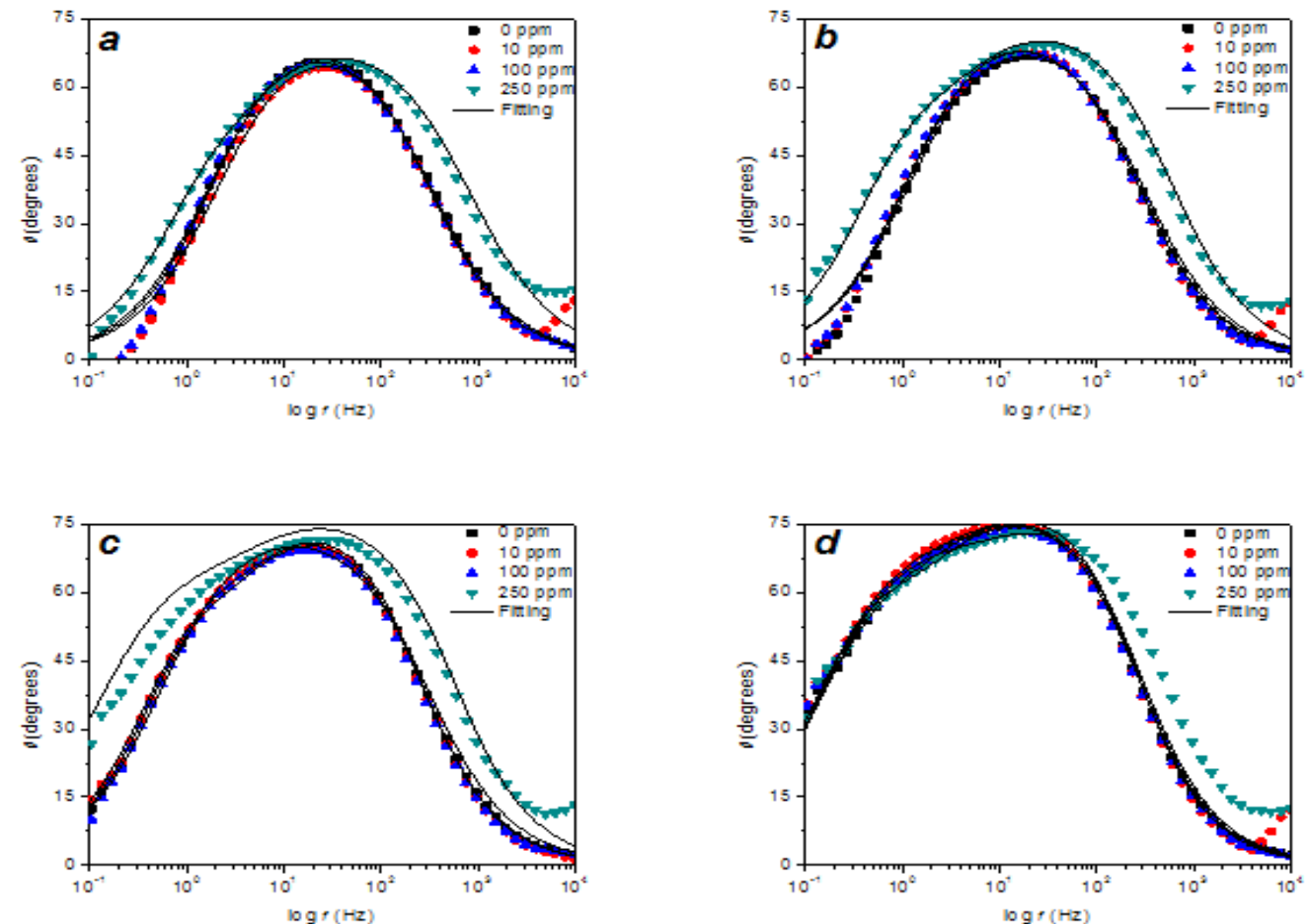

Figure 6: Bode plots of AISI 1018 in a brine solution NACE $+\mathrm{CO}_{2}$ in absence and presence of Leu after a) $\left.\left.0 \mathrm{~h}, \mathrm{~b}\right) 6 \mathrm{~h}, \mathrm{c}\right) 12 \mathrm{~h}$ and d) $24 \mathrm{~h}$ of immersion

Table 2: Impedance parameters calculated from EIS diagrams of AISI 1018 in sweet brine as a function of Leucine concentration and immersion time

\begin{tabular}{|c|c|c|c|c|c|c|c|c|}
\hline $\begin{array}{c}\text { C } \\
(\mathrm{ppm})\end{array}$ & $\begin{array}{c}\text { t } \\
\text { (h) }\end{array}$ & $\begin{array}{c}\mathbf{R}_{\mathbf{f}} \\
\left(\Omega \mathrm{cm}^{2}\right)\end{array}$ & $\begin{array}{c}C_{f}\left[\times 10^{-4}\right] \\
\text { (F) }\end{array}$ & $\begin{array}{c}R_{\mathrm{ct}} \\
\left(\Omega \mathrm{cm}^{2}\right)\end{array}$ & $\begin{array}{c}C_{d l}\left[\times 10^{-4}\right] \\
\text { (F) }\end{array}$ & $\begin{array}{c}R_{p} \\
\left(\Omega \mathrm{cm}^{2}\right)\end{array}$ & $\begin{array}{c}i_{\text {corr }}\left[\times 10^{-5}\right] \\
\left(A / \mathrm{cm}^{2}\right)\end{array}$ & $\begin{array}{c}\text { CR } \\
(\mathrm{mm} / \mathrm{y})\end{array}$ \\
\hline \multirow{4}{*}{0} & 0 & - & - & 715 & 1.23 & 715 & 3.64 & 0.421 \\
\hline & 6 & - & - & 870 & 1.61 & 870 & 2.99 & 0.346 \\
\hline & 12 & - & - & 1791 & 1.67 & 1791 & 1.45 & 0.168 \\
\hline & 24 & 1663 & 1.17 & 3735 & 1.23 & 5398 & 0.482 & 0.055 \\
\hline \multirow{4}{*}{10} & 0 & 540.2 & 1.43 & - & - & 540.2 & 4.81 & 0.557 \\
\hline & 6 & 830.8 & 1.77 & - & - & 830.8 & 3.13 & 0.362 \\
\hline & 12 & 666.2 & 1.29 & 1090 & 1.49 & 1756.2 & 1.48 & 0.171 \\
\hline & 24 & 801.2 & 1.11 & 4708 & 1.03 & 5509.2 & 0.472 & 0.054 \\
\hline \multirow{4}{*}{100} & 0 & 779.9 & 1.22 & - & - & 779.9 & 3.33 & 0.386 \\
\hline & 6 & 1019 & 1.47 & - & - & 1019 & 2.55 & 0.295 \\
\hline & 12 & 890.8 & 1.16 & 1003 & 1.50 & 1893.8 & 1.37 & 0.159 \\
\hline & 24 & 583 & 0.893 & 4982 & 0.912 & 5565 & 0.467 & 0.054 \\
\hline \multirow{4}{*}{250} & 0 & 593.7 & 1.69 & 178.4 & 4.83 & 772.1 & 3.36 & 0.390 \\
\hline & 6 & 692.3 & 1.67 & 662.8 & 2.04 & 1355.1 & 1.92 & 0.222 \\
\hline & 12 & 745.7 & 1.44 & 2346 & 1.70 & 3091.7 & 0.840 & 0.097 \\
\hline & 24 & 874.9 & 1.47 & 3381 & 1.41 & 4255.9 & 0.611 & 0.071 \\
\hline
\end{tabular}



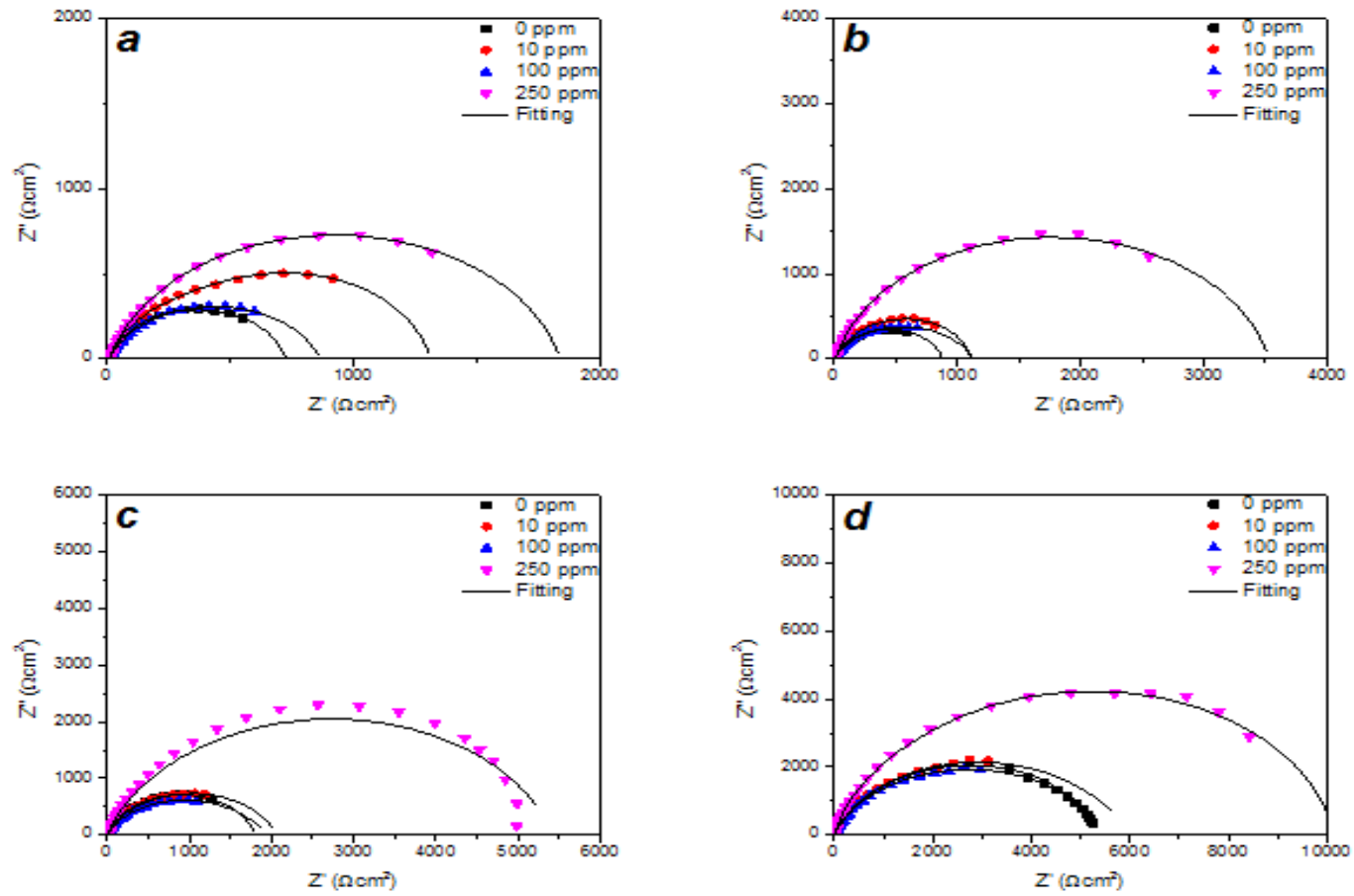

Figure 7: Nyquist plots for AISI 1018 in a brine solution NACE $+\mathrm{CO}_{2}$ in absence and presence of Val after a) $\left.\left.0 \mathrm{~h}, \mathrm{~b}\right) 6 \mathrm{~h}, \mathrm{c}\right) 12 \mathrm{~h}$ and d) $24 \mathrm{~h}$ of immersion
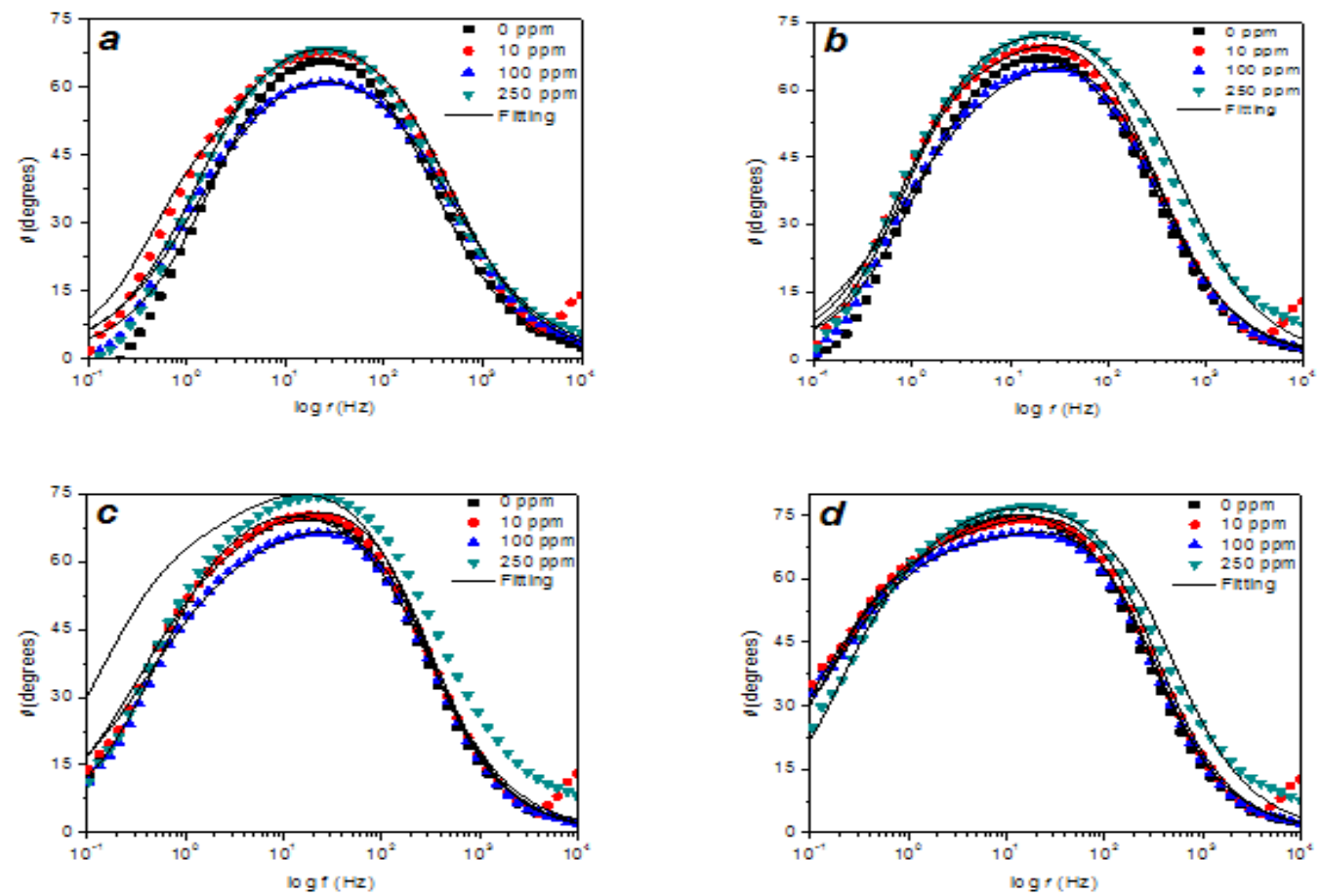

Figure 8: Bode plots of AISI 1018 in a brine solution NACE $+\mathrm{CO}_{2}$ in absence and presence of Val after a) $0 \mathrm{~h}, \mathrm{~b}$ ) $\left.6 \mathrm{~h}, \mathrm{c}\right) 12 \mathrm{~h}$ and d) $24 \mathrm{~h}$ of immersion

Citation: León González JP, Onofre Bustamante E, Rodríguez GómezFJ (2021) Electrochemical Behaviour of Some Amino Acids as 
be appreciated one well defined time constant associated with the amino acid film resistance (Rf) and after 12 and $24 \mathrm{~h}$ of immersion; the widening of the phase angle signal implies a second time constant associated to the charge transfer resistance (Rct). In Table 3 can be seen the data obtained by the fitting of the impedance results; with presence of Val; the double layer capacitance decreases; which implies its adsorption by the changing of the electrical permittivity of the film.

The difference in the concentration when the higher inhibitory effect is achieved by each amino acid is associated to the different molecular structure [25,26]; since the three amino acids interacts with the metal surface by the interaction of the lone-pair electron of the heteroatoms [27], the presence of an aromatic ring in the Phe provides it of a higher electronic density; so that $\pi$-electrons of the benzene ring have donor-acceptor interactions with the vacant d-orbital of the metal surface $[28,29]$.

\section{Polarization Resistance (Rp)}

The effect of immersion time on the AISI 1018 resistance in the sweet brine is shown in Figure9; in case of Phe (Figure 9a); can be appreciated a superior corrosion inhibition at concentration of $10 \mathrm{ppm}$. In addition; the Rp values increases initially followed by a subsequent leveling after $12 \mathrm{~h}$; indicating a gradual reaction of the molecule with the metal surface followed by a surface saturation of simultaneous adsorption-desorption phenomenon [30].

With Leu addition (Figure 9b); the system resistance hardly increases compared with blank; meaning in a slightly protection; agreeing with what was observed in the impedance results. Finally; with Val (Figure 9c) can be seen a superior corrosion protection with a gradual enhancing within immersion time; due to the formation of the amino acid film over the substrate surface.
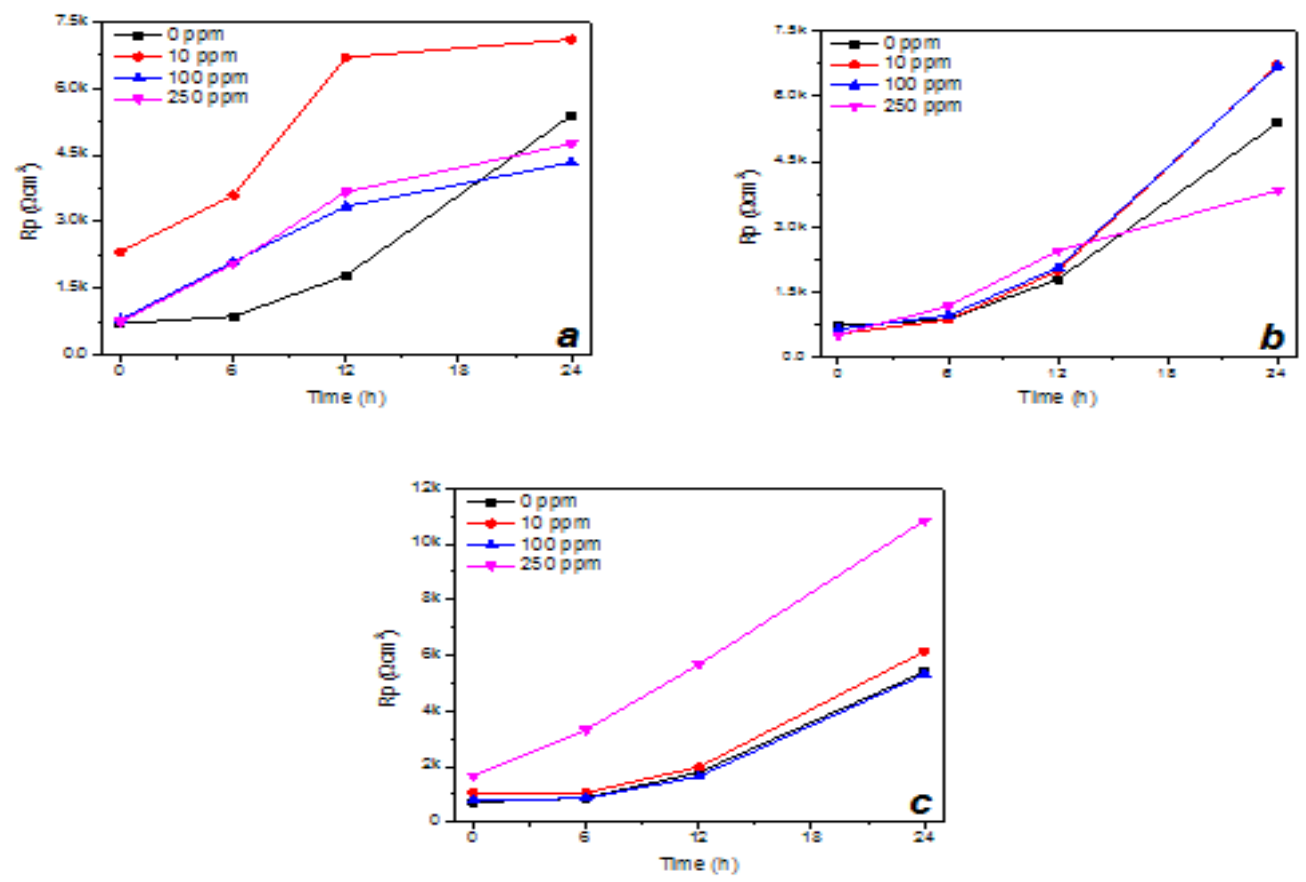

Figure 9: Variation of linear polarization resistance with immersion time with different concentrations of a) Phe, b) Leu and c) Val

\section{Amino acids inhibition efficiency}

Polarization resistance was taken for amino acids Inhibition Efficiency (I.E.) calculations as follows:

$$
\text { I.E. }=\left(\frac{R p_{\text {inh }}-R p_{0}}{R p_{\text {inh }}}\right) \cdot 100
$$

where $R p_{0}$ and $\mathrm{Rp}_{\text {inh }}$ are the polarization resistances in absence and presence of corrosion inhibitor; respectively [31] and results are shown in Figure 10. As immersion time increases; the polarization resistance also increases due to further amino acid adsorption; and consequently the inhibition efficiency increases up to 89; 87 and $93 \%$ for Phe; Leu and Val; respectively. It should be noted that in case of Phe; the I.E. achieves $89 \%$ since the first $12 \mathrm{~h}$ of immersion; and remains constant for 12 more hours; in comparison with Leu and Val which reach their highest efficiency after $24 \mathrm{~h}$.

\section{Adsorption isotherms and thermodynamics}

The usual mechanism in which organic corrosion inhibitors provide anticorrosive protection is by their adsorption over the metal surface; insolating it from the aggressive electrolyte and preventing the substrate dissolution [32]. For a further analysis 
of adsorption processes carried out in the system; the implementation of adsorption isotherms provides information about the nature of the interactions between the corrosion inhibitor molecule and the metal surface [33]. The adsorption process is influenced by many factors; as the metal charge; chemical nature of metal and organic compound or charge distribution on the molecule [34]. When considering adsorption isotherms; it is conventional to adopt the term surface coverage $(\theta)$; which defines the saturation of a particular adsorbate on a given surface [35]. It can be calculated by the following equation:

$$
\theta=0.01\left(\frac{R p_{\text {inh }}-R p_{0}}{R p_{\text {inh }}}\right)
$$
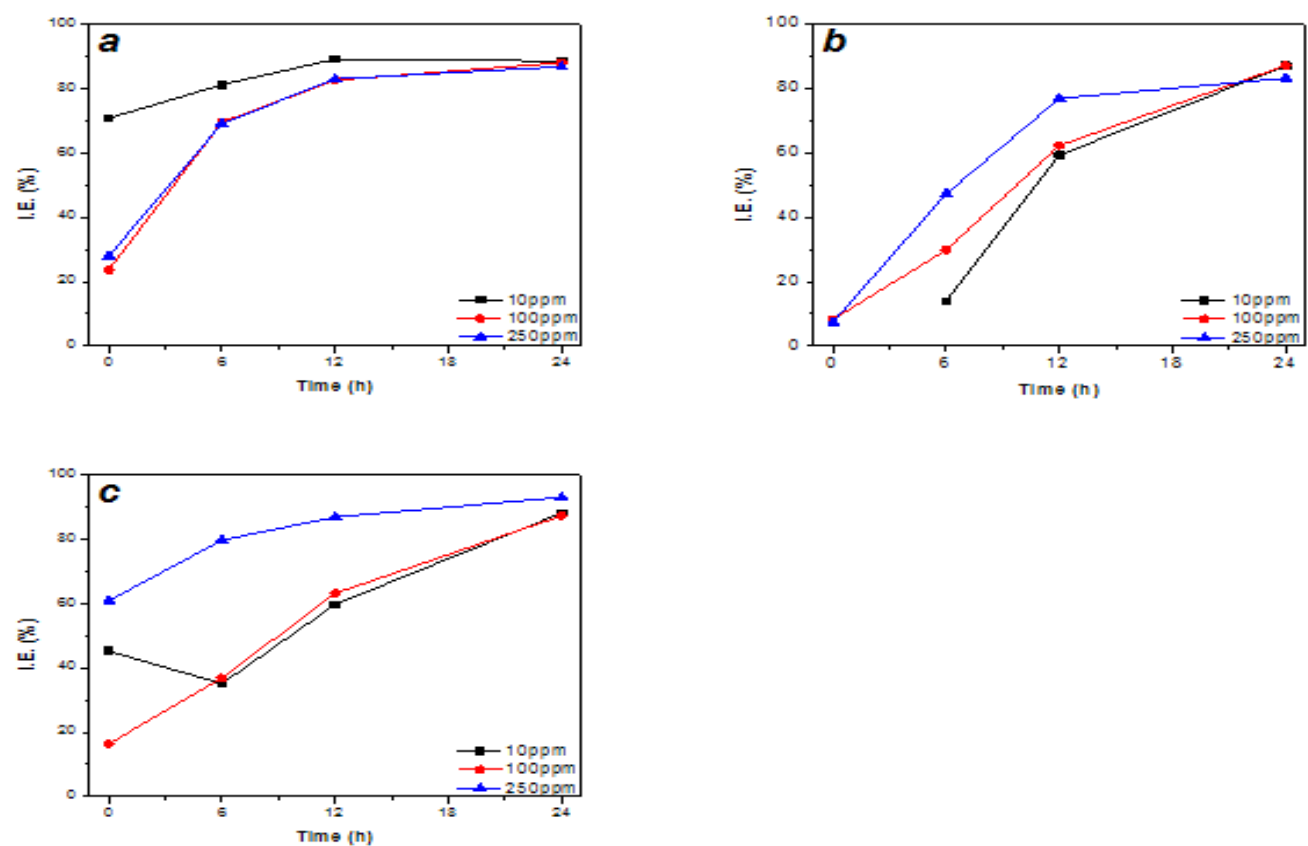

Figure 10: Efficiencies of the different concentration of a)Phe, b) Leu and c) Val for AISI 1018 in a sweet brine in continuous immersion

where the value of $\theta$ must be in the interval of $0-1$. When $\theta=0$; implicates the lack of surface coverage of the corrosion inhibitor and at the case of $\theta=1$ implies the total coverage of substrate surface [36]. There are several adsorption isotherms models used for thermodynamic analysis; some of them are: Langmuir; Temkin;Freundlich;Frumkin; Fory-Huggins or Bockris-Swinkels (Abd El Rehim et al; 2016). The three amino acids systems adjusted more accurately to Langmuir's model; given by the following equation:

$$
\frac{C}{\theta}=\frac{1}{K_{a d s}}+C
$$

where $C$ is the corrosion inhibitor concentration (mol/L) and $\mathrm{K}_{\text {ads }}$ is the adsorption constant[37].In order to determinate the adsorption model; it is important to calculate the Gibbs free energy of adsorption $\left(\Delta \mathrm{G}^{0}{ }_{\text {ads }}\right)$ which is related with the adsorption constant $\left(\mathrm{K}_{\mathrm{ads}}\right)$ by the following equation:

$$
\Delta G_{a d s}^{0}=-R T \ln K_{a d s}
$$

where $R$ is the ideal gas constant and $\mathrm{T}$ is the absolute temperature $(\mathrm{K})$.

If the Gibbs free energy gets negative values; a spontaneous process is happening (Cleveland and Morris; 2014). When there is a physical interaction (physisorption) between amino acids and metal surface then $\Delta \mathrm{G}_{\mathrm{ads}}<-20 \mathrm{~kJ} / \mathrm{mol}$;for a chemical interaction (chemisorption) $\Delta \mathrm{G}_{\mathrm{ads}}>-40 \mathrm{~kJ} / \mathrm{mol}$; and for values of $-20 \mathrm{~kJ} / \mathrm{mol}<$ $\llbracket \Delta \mathrm{G} \rrbracket_{\mathrm{ads}}<-40 \mathrm{~kJ} / \mathrm{mol}$ there is a combined process of physisorption and chemisorption[38].

In Figure 11 can be appreciated the adsorption isotherms of the three amino acids (Phe;Leu and Val) and in table 4 is shown the thermodynamic data calculated from them. It can be seen that for Phe; at all immersion times the $\Delta \mathrm{G}_{\text {ads }}$ values are near $-40 \mathrm{~kJ} /$ mol meaning a chemisorption in comparison with Leu and Val 

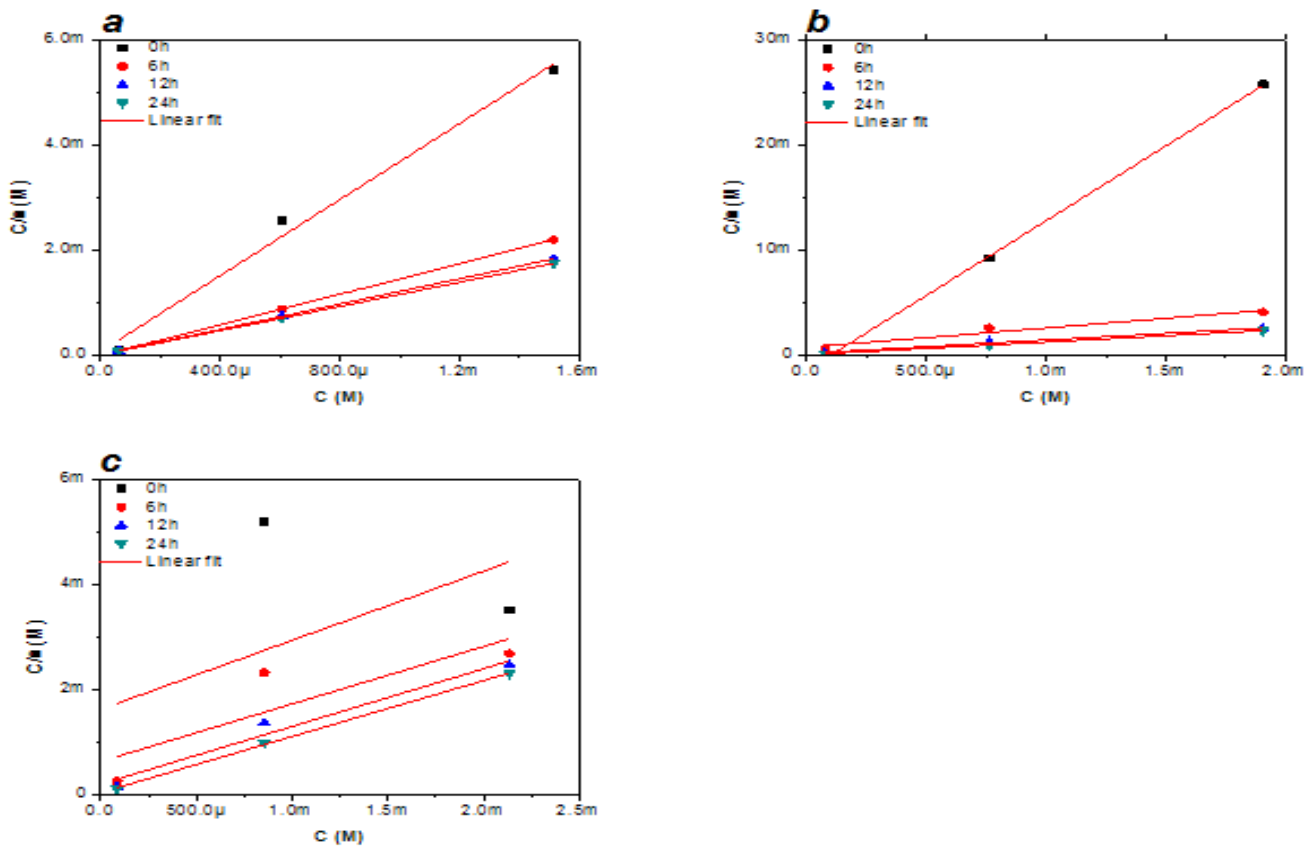

Figure 11: Adsorption model adopted from the experimental results according to the theoretical model of Langmuir

\begin{tabular}{|c|c|c|c|c|c|c|c|c|}
\hline $\begin{array}{c}C \\
(\mathrm{ppm})\end{array}$ & $\begin{array}{c}t \\
(\mathrm{~h})\end{array}$ & $\begin{array}{c}\mathbf{R}_{\mathbf{f}} \\
\left(\Omega \mathrm{cm}^{2}\right)\end{array}$ & $\begin{array}{c}C_{f}\left[x 10^{-4}\right] \\
\text { (F) }\end{array}$ & $\begin{array}{c}\mathbf{R}_{\mathrm{ct}} \\
\left(\Omega \mathrm{cm}^{2}\right)\end{array}$ & $\begin{array}{l}C_{\text {dil }}\left[\mathrm{x} 10^{-4}\right] \\
\text { (F) }\end{array}$ & $\begin{array}{c}\mathbf{R}_{\mathrm{p}} \\
\left(\Omega \mathrm{cm}^{2}\right)\end{array}$ & $\begin{array}{c}i_{\text {corr }}\left[\mathrm{x} 10^{-5}\right] \\
\left(\mathrm{A} / \mathrm{cm}^{2}\right)\end{array}$ & $\begin{array}{c}\mathrm{Xcorr} \\
(\mathrm{mm} / \mathrm{y})\end{array}$ \\
\hline \multirow{4}{*}{0} & 0 & - & - & 715 & 1.23 & 715 & 3.64 & 0.421 \\
\hline & 6 & - & - & 870 & 1.61 & 870 & 2.99 & 0.346 \\
\hline & 12 & - & - & 1791 & 1.67 & 1791 & 1.45 & 0.168 \\
\hline & 24 & 1663 & 1.17 & 3735 & 1.23 & 5398 & 0.482 & 0.055 \\
\hline \multirow{4}{*}{10} & 0 & 993.5 & 1.23 & - & - & 993.5 & 1.99 & 0.231 \\
\hline & 6 & 551.4 & 1.17 & 549.8 & 0.967 & 1101.2 & 2.36 & 0.273 \\
\hline & 12 & 491.3 & 1.11 & 1282 & 1.11 & 1773.3 & 1.46 & 0.169 \\
\hline & 24 & 604.5 & 0.939 & 5404 & 1.06 & 6008.5 & 0.432 & 0.050 \\
\hline \multirow{4}{*}{100} & 0 & 855.3 & 1.37 & - & - & 855.3 & 3.04 & 0.352 \\
\hline & 6 & 237.4 & 0.869 & 895.5 & 1.14 & 1132.9 & 2.29 & 0.265 \\
\hline & 12 & 216.9 & 0.840 & 1723 & 2.41 & 1939.9 & 1.34 & 0.155 \\
\hline & 24 & 360.8 & 0.786 & 5233 & 1.16 & 5593.8 & 0.464 & 0.053 \\
\hline \multirow{4}{*}{250} & 0 & 1826 & 0.702 & - & - & 1826 & 1.42 & 0.165 \\
\hline & 6 & 3515 & 0.551 & - & - & 3515 & 0.739 & 0.085 \\
\hline & 12 & 1269 & 1.09 & 4164 & 1.08 & 5433 & 0.478 & 0.055 \\
\hline & 24 & 7239 & 0.521 & 2890 & 0.916 & 10129 & 0.256 & 0.029 \\
\hline
\end{tabular}

where $\Delta \mathrm{G}_{\mathrm{ads}}$ are in the range of -20 and $-40 \mathrm{~kJ} / \mathrm{mol}$ meaning in a combined process; which implies a weaker interaction with the metal surface; agreeing with results seen in the electrochemical characterization.

\section{Morphological Characterization}

\section{Scanning Electronic Microscopy (SEM)}

In Figure 12 can be appreciated the surface morphology images of the polished AISI 1018 steel sample (figure 12a); and the steel sample after $24 \mathrm{~h}$ of immersion in the aggressive electrolyte with $10 \mathrm{ppm}$ of Phe (Figure 12b); $100 \mathrm{ppm}$ of Leu (Figure 12c) and $250 \mathrm{ppm}$ of Val (Figure 12d). It can be observed that the polished line of the sample can still be seen after the $24 \mathrm{~h}$ immersion in the presence of the three amino acids; meaning that organic molecules adsorbed in those areas forming a protecting layer and inhibiting the metal dissolution; the agglomerations seen in images are associated to corrosion products and $\mathrm{NaCl}$ incrustations due to the presence of $\mathrm{Na}$ and $\mathrm{Cl}$ signals in EDX images $[39,40]$. The cluster presence in substrate surface validates electrochemical results; since the system with 

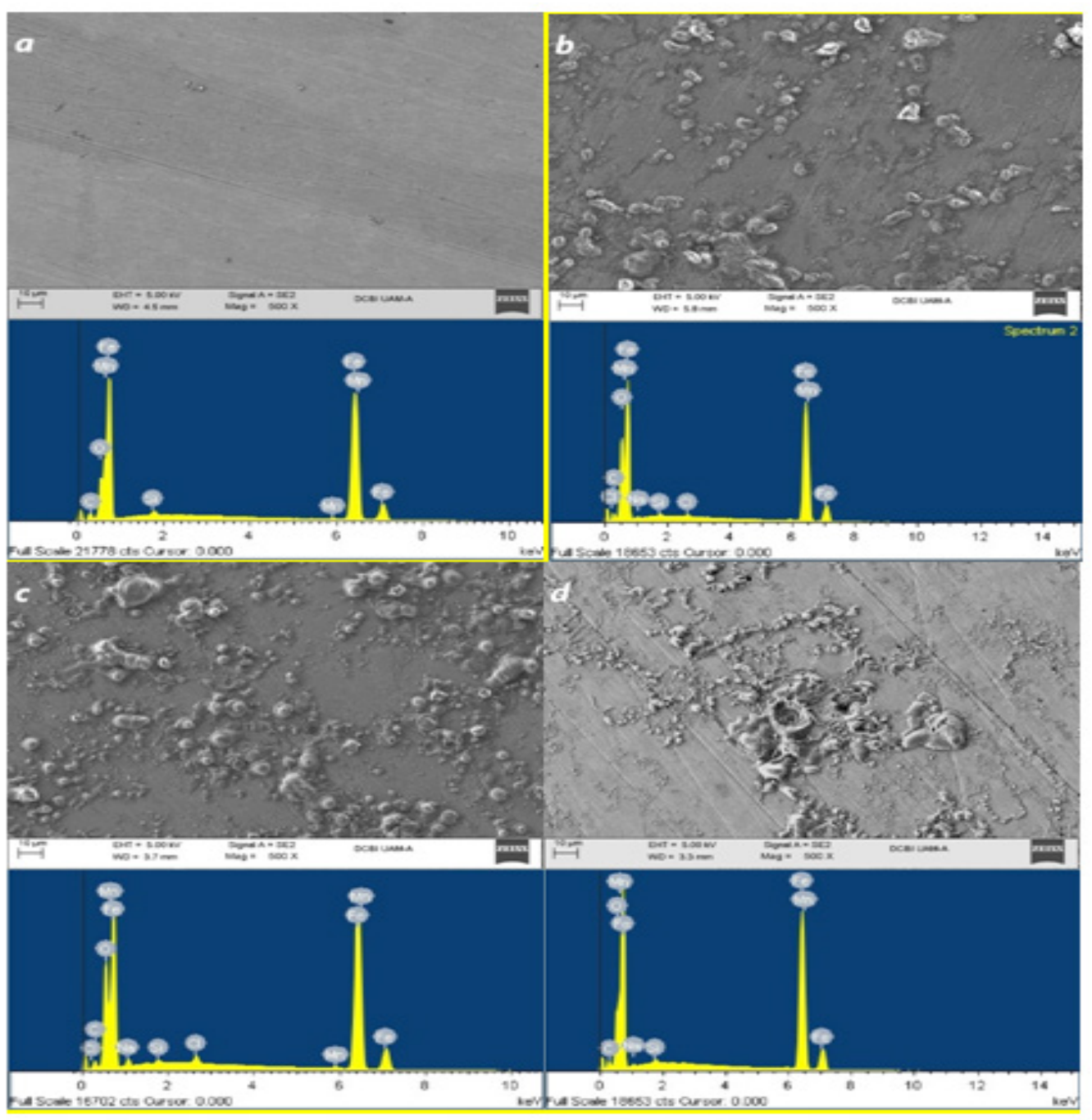

Figure 12: SEM and EDX images of (a) pulished substrate and with (b) phenylalanine, (c) leucine and (d) valine afeter $24 \mathrm{~h}$ immersion in the sweet brine
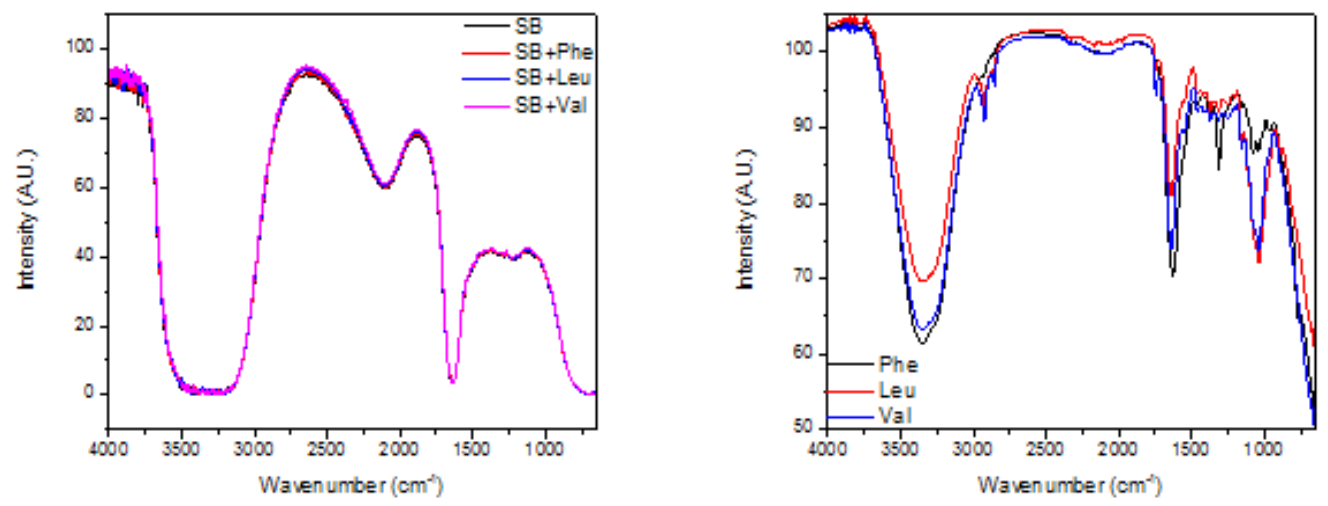

Figure 13: Transmission spectra of brine solution NACE $+\mathrm{CO}_{2}$ in absence and presence of amino acids a) at beggining of tests and b) after seven days

Citation: León González JP, Onofre Bustamante E, Rodríguez GómezFJ (2021) Electrochemical Behaviour of Some Amino Acids as Page 11 of 14 Corrosion Inhibitors for Mild Steel in Sweet Brine. SOJ Mater Sci Eng 8(1): 1-14. 


\begin{tabular}{|c|c|c|c|c|c|c|}
\hline Amino acid & t (h) & $\mathrm{K}_{\text {ads }}$ & $\Delta G_{\text {ads }}(\mathrm{kJ} / \mathrm{mol})$ & $m$ & $\mathbf{R}^{2}$ & Adsorptiontype \\
\hline \multirow{4}{*}{ Phe } & 0 & $1.09 \mathrm{E} 7$ & -39.61 & 3.626 & 0.9795 & Chemisorption \\
\hline & 6 & $1.20 \mathrm{E} 7$ & -39.84 & 1.456 & 1 & Chemisorption \\
\hline & 12 & $2.16 \mathrm{E} 7$ & -41.28 & 1.208 & 0.9999 & Chemisorption \\
\hline & 24 & $1.06 \mathrm{E} 7$ & -39.54 & 1.154 & 0.9999 & Chemisorption \\
\hline \multirow{4}{*}{ Leu } & 0 & $3.77 \mathrm{E} 4$ & -25.76 & 14.24 & 0.9995 & Combined \\
\hline & 6 & $8.01 \mathrm{E} 4$ & -27.70 & 1.843 & 0.8954 & Combined \\
\hline & 12 & 4.63E5 & -31.89 & 1.265 & 0.9782 & Combined \\
\hline & 24 & $2.72 \mathrm{E} 6$ & -36.21 & 1.207 & 0.9992 & Combined \\
\hline \multirow{4}{*}{ Val } & 0 & $3.42 \mathrm{E} 4$ & -25.52 & 1.319 & 0.4268 & Combined \\
\hline & 6 & $8.92 \mathrm{E} 4$ & -27.86 & 1.096 & 0.4930 & Combined \\
\hline & 12 & $2.95 \mathrm{E} 5$ & -30.78 & 1.102 & 0.9433 & Combined \\
\hline & 24 & $1.91 \mathrm{E} 6$ & -33.35 & 1.068 & 0.9982 & Combined \\
\hline
\end{tabular}

Phe present the less agglomeration areas; followed by the system with Leu and finally with Val $[41,42]$.

\section{Spectroscopic characterization}

\section{Fourier Transform Infrared Spectroscopy (FTIR)}

The FTIR spectrum of the Sweet Brine (SB) with the different amino acids is shown in Figure 13a. The width peak observed in the range of $3000-3500 \mathrm{~cm}-1$ is attributed to the $0-\mathrm{H}$ stretching vibrations (v1); the sharp peak in $1640 \mathrm{~cm}^{-1}$ is attributed to the $\mathrm{O}-\mathrm{H}$ bending vibrations ( $\mathrm{v} 2$ ) and at $2100 \mathrm{~cm}-1$ is the combination band(v1+v2)[43] . As can be seen; it is basically the water FTIR spectrum due to the fact that characteristic bond of amino acids was not detected due to their low concentration in the solution. In figure $13 \mathrm{~b}$ can be appreciated the spectrum of the same solutions after seven days; where agglomerations could be distinguished. The most intense peak is attributed to the $\mathrm{O}-\mathrm{H}$ stretching vibrations[44]; the peak in the range of $1700-1500 \mathrm{~cm}-1$ is associated to the $\mathrm{C}=\mathrm{O}$ and $\mathrm{C}-\mathrm{N}$ stretching vibrations [45-48]; the last related to the peptide bond which suggests that amino acid molecules tend to agglomerate within time; diminishing their efficiency as corrosion inhibitors.

\section{Conclusion}

In order to contribute the necessitated development of new natural; inexpensive and environmentally friendly corrosion inhibitors; this research work determinate the following results:

From the electrochemical results; it was determinate that the proposed amino acids are a good ecological alternative as corrosion inhibitors for AISI 1018 in sweet brine due to the system corrosion resistance increasing.

It was determinate that the amino acids form a monolayer on metal surface due to the systems fit the Langmuir's adsorption isotherms. It was also concluded that Phe needs lower concentration to inhibit corrosion due to its molecular structure; which provides it of a higher electronic density by the aromatic ring; improving the interaction between amino acid and metal surface; inducing chemisorption. In comparison with Leu and Val where the absence of the benzene ring leads to weaker bonds with the iron in surface; having a combination of physical and chemical interactions.

The amino acids presence prevents the metal dissolution; as can be seen in the SEM images; where the areas where the polished lines are still visible were where the inhibitor was adsorbed and protected the substrate.

The inhibition efficiency of the amino acids would decrease within time due to desorption process and due to their agglomeration in solution bulk; which could be seen in FTIR by the appearance of the $\mathrm{C}-\mathrm{N}$ vibrational band associated to the peptide bond between amino acids.

\section{Authors' contributions}

León-González carried out the electrochemical studies of amino acids and participated in electrochemical; thermodynamic; morphological and spectroscopic analysis and drafted the manuscript.

Onofre-Bustamante and Rodríguez-Gómez participated in electrochemical and morphological analysis; design of the study; project administration; funding acquisition and supervision.

Espinoza-Vázquez participated in electrochemical; thermodynamic and spectroscopic analysis for amino acids and supervision.All the authors read and approved the final manuscript.

\section{Acknowledgments}

The authors express their gratitude to the Instituto Politécnico Nacional (IPN); Centro de Investigación en CienciaAplicada y TecnologíaAvanzada - Unidad Altamira 
(CICATA-Altamira) and to Universidad Nacional Autónoma de México (UNAM);Departamento de Ingeniería Metalúrgica for the facilities for laboratory experimentation; the Divisional Electronic Microscopy Laboratory of DCBI of UAM-Azcapotzalco for the use of Zeiss SUPRA 55 VP microscope; and to SIP project 20201452 for resource funding. JPLG wishes to acknowledge the ConsejoNacional de Ciencia y Tecnología (CONACyT) for scholarship.

\section{References}

1. Kermani B, Harrop D. Corrosion and Materials in Hydrocarbon Production: A Compendium of Operational and Engineering Aspects. Wiley. 2019.

2. Popoola LT, Grema AS, Latinwo GK, Gutti B, Balogun AS. Corrosion problems during oil and gas production and its mitigation. Int J Ind Chem. 2013;4(1):35

3. Olajire AA. Corrosion inhibition of offshore oil and gas production facilities using organic compound inhibitors - A review. J Mol Liq 2017;248:775-808

4. Sastri VS. Green corrosion inhibitors: theory and practice. Wiley, Singapore. 2011.

5. El Ibrahimi B, Jmiai A, Bazzi L, El Issami S. Amino acids and their derivatives as corrosion inhibitors for metals and alloys. Arab Chem.2020;13(1):740-771

6. Hamadi L, Mansouri S, Oulmi K, Kareche A. The use of amino acids as corrosion inhibitors for metals: A review. Egyp J Petrol. 2018;27(4):1157-1165

7. Bobina M, Kellenberger A, Millet J, Muntean C, Vaszilcsin N. Corrosion resistance of carbon steel in weak acid solutions in the presence of L-hisitidine as corrosion inhibitor. Corr Sci. 2013;69:389-395

8. Singh P, Bhrara K and Singh G. Adsorption and kinetic studies of L-leucine as an inhibitor on mild steel in acidic media. Appl Surf Sci. 2008;254:5927-5935

9. Zhang D, Cai Q He X, Gao L, Kim GS. Corrosion inhibition and adsorption behavior of methionine on copper in $\mathrm{HCl}$ and synergistic effect of zinc ions. Mater. Chem. Phys. 2009;114:612-617

10. Yadav M, Gope L and Sarkar TK. Synthesized amino acid compound as eco-friendly corrosion inhibitors for mild steel in hydrochloric acid solution: electrochemical and quantum studies. Res Chem Intermed. 2015;2(3):2641-2660

11. Gupta NK, Verma C, Quraishi MA, Mukherjee AK. Schiff's bases derived from L-lysine and aromatic aldehydes as green corrosion inhibitors for mild steel: Experimental and theoretical studies. J Mol Liq. 2016;215:47-57

12. Ashassi-Sorkhabi H, Asghari E. Effect of hydrodynamic conditions on the inhibition performance of L-methionine as a green inhibitior. Electrochim Acta 2008;54:162-167

13. Nady H. Tricine [N-(Tri(hydroxymethyl)methyl)glycine] - A novel green inhibitor for the corrosion inhibition of zinc in neutral aerated sodium chloride solution. Egypt J Petrol. 2017;26:905-913

14. Hamed E, El-Rehim SS, El-Shahat, Shaltot AM. Corrosion inhibition of nickel in $\mathrm{H} 2 \mathrm{SO} 4$ solution by alanine. Mater Sci Eng B. 2012;177:441-448

15. Zhang D, Wu H, Gao L. Synergistic inhibition effect of
L-phenylalanine and rare earth Ce(IV) ion on the corrosion of copper in hydrochloric acid solution. Mater Chem Phys. 2012;133:981-986

16. Espinoza-Vázquez A, Gómez FJ. Caffeine and nicotine in 3\% $\mathrm{NaCl}$ solution with $\mathrm{CO} 2$ as corrosion inhibitors for low carbon steel. RSC Adv. 2016;6:70226-70236

17. Bentiss F, Lebrini M, Lagreneé M. Thermodynamic characterization of metal dissolution and inhibitor adsorption processes in mild steel/2,5-bis(n-thienyl)-1,3,4-thiadiazoles/ hydrochloric acid system. Corr Sci. 2005;47(12):2915-2931

18. Kothari K, Ragoonanan V, Suryanarayanan R. The role of polymer concentration on the molecular mobility and physical stability of nifedipine solid dispersions. Mol Pharmaceutics. 2015;12(5):14771484

19. Dehghani A, Poshtiban F, Bahlakeh G, Ramezanzadeh B. Fabrication of metal-organic based complex film based on three-valent samarium ions-[bis (phosphonometyl) amino] methylphophonic acid (ATMP) for effective corrosion inhibition of mild steel in simulated seawater. Con Build Mat. 2020;239:117812-117827

20. Zhang Z, Tian N, Zhang W, Huang X, Ruan L, Wu L. Inhibition of carbon steel in phase-change-materials solution by methionine and proline. Corr Sci. 2016;111:675-689

21. Tildiz R. An electrochemical and theoretical evaluation of 4,6-diamino-2-pyrimidinethiol as a corrosion inhibitor for mild steel in $\mathrm{HCl}$ solutions. Corr Sci. 2014;90:544-553

22. Vieira DS, Fernandes PRG, Mukai H, Zola RS, Gonçalves-Lenzi G, et al. Surface roughness on CPE parameters in electrolytic cells. Int J Electrochem Sci. 2016;11:7775-7784

23. Tang Y, Zhang F, Hu S, Cao Z, Wu Z, et al. Novel benzimidazole derivatives as corrosion inhibitors of mild steel in the acidic media. Part I: Gravimetric, electrochemical, SEM and XPS studies. Corr Sci. 2013;74:271-282

24. Wang H, Shi H, Hong T, Kang C, Jepson W. Characterization of inhibitor and corrosion product film using electrochemical impedance spectroscopy (EIS). NACE Int. Corr. Conference and Expo. 2001.

25. Guo L, Ren X, Zhou Y, Xu S, Gong Y, Zhang S. Theoretical evaluation of the corrosion inhibition performance of 1,3-thiazole and its amino derivatives. Arab J Chem. 2017;10(1):121-130

26. Martínez S, Staglijar I. Correlation between the molecular structure and the corrosion inhibition efficiency of chesnut tannin in acidic solutions. J Mol Struc-THEOCHEM. 2003;640(1-3):167-174

27. Vinutha MR and Venkatesha TV. Review on mechanistic action of inhibitors on steel corrosion in acidic media. Port Electrochim Acta. 2016;34(3):157-184

28. Eddy NO. Experimental and theoretical studies on some amino acids and their potential activity as inhibitors for the corrosion of mil steel. part 2. J Adv Research. 2010;2:35-47

29. Fu J, Li S, Wang Y, Liu X, Lu L. Computational and electrochemical studies on the inhibition of corrosion of mild steel by l-cysteine and its derivatives. J Mat Sci 2011;46(10):3550-3559

30. Taheri P, Milosev I, Meeusen M, Kapun B, White P, et al. On the importance of time-resolved electrochemical evaluation in corrosion inhibitor-screening studies. NPJ Mater Degrad. 2020;4(1).

31. Öskir D, Bayol E, Gürten AA, Sürme Y. Thermodynamic study and electrochemical investigation of calcein as corrosion inhibitor for 
mild steel in hydrochloric acid solution. J Chil. 2013;58(4):2158-2167

32. Goyal M, Kumar S, Bahadur I, Verma C, Ebendo EE. Organica corrosion inhibitors for industrial cleaning of ferrous and non-ferrous metals in acidic solutions: A review. J Mol Liq. 2018;256:565-573

33. Khulood AA, Al-Ola A, Al-Nami SY. 1-Benzoyl-4-phenyl-3thiosemicarbazide as corrosion inhibitor for carbon steel in H3PO4 solution. Mod Appl Sci. 2011;5(3):193-206

34. Obot IB, Obi-Egbedi NO. Ginseng root: a new efficient and effective eco-friendly corrosion inhibitor for alluminium alloy of type AA 1060 in hydrochloric acid solution. Int J Electrochem Sci. 2009;4:1277-1288

35. McQuarrie DE, Simon JD. Physical Chemistry: A molecular approach. University Science Books. 1997.

36. Ituen E, Akaranta 0, James A. Evaluation of performance of corrosion inhibitors using adsorption isotherm models: An overview. Chem Sci Int J. 2017;18(1):1-34

37. Abdullah A. Adsorption isotherm of some triazoles as corrosion inhibitors of mild steel in acids. AL-Fatih Journal. 2008;32

38. Ali Fil B, Korkmaz M, Özmetin G. An empirical model for adsorption thermodynamics of copper (II) from solutions onto illite clay-batch process design. J Chil Chem Soc. 2014;59(4):2686-2691.

39. Singh DK, Ebenso EE, Sinh MK, Behera D, Udayabhanu G, John RP. Non-toxic Schiff bases as efficient corrosion inhibitors for mild steel in 1M HCl: Electrochemical, AFM, FE-SEM and theoretical studies. J Mol Liq. 2017;250:88-99

40. Vengatesh $\mathrm{G}$ and Sundaravadivelu M. Non-toxic bisacodyl as an effective corrosion inhibitor for mild steel in 1M HCl: Thermodynamic, electrochemical, SEM, EDX, AFM, FT-IR, DFT and molecular dynamics simulations studies. J Mol Liq. 2019;287:110906-110920
41. Fatima S, Sharma R, Asghar F, Kamal A, Badshah A, et al. Study of new amphiphiles based on ferrocene containing Thioureas as Efficient Corrosion Inhibitors: Gravimetric, Electrochemical, SEM and DFT studies. J Ind Eng Chem. 2019;763:74-387

42. Ech-chinbi E, Nahlé A, Salim R, Benhiba F, Moussaif A, et al. Computational, MD simulation, SEM/EDX and experimental studies for understanding adsorption of benzimidazole derivatives as corrosion inhibitors in 1.0 M HCl solution. J Alloys Compd. 2020;844:155842

43. Nakamoto K. Infrared and Raman spectra of inorganic and coordination compounds, Part A: Theory and applications in inorganic chemistry. Wiley. 2009.

44. Bulgariu L, Escudero LB, Bello OS, Iqbal M, Nisar J, et al. The utilization of leaf-based adsorbents for dyes removal: A review. J Mol Liq. 2019;276:728-747

45. Krimm S, Bandekar J. Vibrational spectroscopy and conformation of peptides, polypeptides and proteins. Adv Protein Chem. 2019;38:181-264

46. Abd Rehim SS, Sayyah SM, El-Deeb MM, Kamal SM, Azooz RE. Adsorption and corrosion inhibitive properties of $P$ (2-aminobenzothiazole) on mild steel in hydrochloric acid media. Int J Ind Chem. 2016;7(1):39-52

47. Fatah HTM, Kamel MM, Hassan AAM, Rashwan SAM, Abd El Wahaab, et al. Adsorption and inhibitive properties of Tryptophan on low alloy steel corrosion in acidic media. Arab J Chem. 2017;10:S1164-S1171

48. Vázquez A, Gómez FJ, Silva GE, Olvera R, Beltrán D, et al. Fluconazole and fragments as corrosion inhibitors of API 5L X52 steel immersed in 1M HCl. Corr Sci. 2020;174:108853

49. Cleveland C, Morris C. Dictionary of energy. Elsevier. 2014. 